\title{
Carbon and oxygen isotopes analyses for the Sinian carbonates in the Helan Mountain, North China
}

\author{
YANG Jie ${ }^{1,2}$, ZENG ZuoXun $^{1,3^{*}}$, CAI XiongFei ${ }^{1}$, LI ZhiYong $^{1,3}$, LI TianBin $^{4}$, MENG Fang $^{5} \&$ \\ HE WenJian ${ }^{6}$
}

${ }^{1}$ Faculty of Earth Sciences, China University of Geosciences, Wuhan 430074, China;

${ }^{2}$ Three Gorges Geotechnical Consultants Co., Ltd., Wuhan 430074, China;

${ }^{3}$ Huazhong Tectonomechanical Research Center, Wuhan 430074, China;

${ }^{4}$ Ningxia Monitoring Institute of Land Resources Survey, Yinchuan 750004, China;

${ }^{5}$ Ningxia Institute of Geological Survey, Yinchuan 750021, China;

${ }^{6}$ Geological Team 292 of the Guangdong Province Nuclear Industry Geological Bureau, Heyuan 517000, China

Received December 19, 2012; accepted March 28, 2013; published online June 24, 2013

\begin{abstract}
We conducted detailed studies of the Sinian carbonates from the Helan Mountain, Ningxia by both field investigation and laboratory analyses of carbon and oxygen isotopes. The carbon isotopic compositions of the Sinian Zhengmuguan Formation shows variations with regularity in the five studied sections, the $\delta^{13} \mathrm{C}$ values all gradually decrease from bottom to top, with a total range from $-4.51 \%$ o to $0.11 \%$, and the biggest negative excursion reaches up to $-6.88 \%$. In addition, abundant macro-body fossils were also found from the Tuerkeng Formation in this study, similar to those found from the Dengying Formation in the South China Block. This observation firmly constrained the age for the Zhengmuguan and Tuerkeng formations to the Sinian period. Here we interpreted that the Zhengmuguan Formation formed during a glacial period when the extremely cold climate substantially decreased the amount of burial of organic matter in the ocean and thus led to the general negative $\delta^{13} \mathrm{C}$ excursion. The increasing $\delta^{13} \mathrm{C}$ values in the Tuerkeng Formation dolomites imply the ending of the glacial period in the Zhengmuguan epoch, biological recovery and increase of organic matter burial in the ocean occurred during this period. Comparing our obtained carbon and oxygen isotopes of the Zhengmuguan and Tuerkeng formations with those of coeval carbonate successions from other places all over the world, the Zhengmuguang-aged glacial deposits might be deposited after the Gaskiers glaciation. This study provides important information for paleo-ocean, paleogeographic and biological evolution in the North China Block during the Ediacaran period and adds new carbon and oxygen isotopes data for the global Sinian carbon-oxygen isotopes dataset.
\end{abstract}

carbon and oxygen isotopes, Sinian carbonate, Helan Mountain, Glacial deposits

Citation: Yang J, Zeng Z X, Cai X F, et al. Carbon and oxygen isotopes analyses for the Sinian carbonates in the Helan Mountain, North China. Chin Sci Bull, 2013, 58: 3943-3955, doi: 10.1007/s11434-013-5857-4

Global-scale glacier events have taken place more than once during the whole geological history. These events are intimately related to the atmospheric $\mathrm{CO}_{2}$ concentrations $[1,2]$, the global climate changes [3-5], biologic extinctions [6], etc. Recently, researches on the Neoproterozoic "snowball Earth events" [7,8], Rodinia supercontinent [9] and cap carbonates [10-13] have made the Neoproterozoic glacial events as new focus around the international geology com-

*Corresponding author (email: zuoxun.zeng@126.com) munity. In China, the Neoproterozoic successions are dominated by carbonates and are mostly distributed in the Tarim [14,15], North China [16] and South China [17-19] blocks. Previous work mainly focuses in the Quruqtagh area of the Tarim Block and the Three Gorges area of the South China Block. Because of the limited outcropping of the Neoproterozoic strata in the North Block (only a suit of mountain glacial and ocean glacial deposits on the southern margin of the Sino-Korean Block), researches on the Neoproterozoic glacial events in the North China Block are limited. By re- 
gional geological surveys, we found a suit of Neoproterozoic tillite, with complex conglomerates, chaotic sequence and stable output layers in the Helan Mountain, Ningxia, North China. This suit of tillite succession has significant implications for the Neoproterozoic glacial events in the North China Block but so far studies on this tillite succession are poor. Tillites are possibly deposited in a quiet or deep oceanic environment in terms of the micritic structure and carbonate cements [20]. Based on systematic studies on the tillites of the Helan Mountain, a simple type (drift furrows type) and a complex type (Tuerkeng type) glaciation phase models were proposed by Zheng et al. [21]. Zhang et al. [22] further suggested that a retreating glacier process occurred from south to north in the Ordos Basin, where ice sheet in the North China Block gradually shrunk into the inner Ordos Basin forming tillites in the terrain sharp transition zone of the southern margin of the North China Block [22]. However, a quantitative and high-resolution study for the isotopic compositions within these tillites is required to fully understand the evolution of the Neoproterozoic tillites in the region.

Carbon and oxygen isotopes of marine carbonate rocks are stable and they have the potential to retain the primary isotopic information of the contemporary seawater. On the other hand, stable carbon isotope of marine sediments correlates closely with ancient climate changes such as the fluctuations in $p \mathrm{CO}_{2}$ and $p \mathrm{O}_{2}$ in the atmosphere $[1,3,23]$. This relation between the surface system evolutions and carbon isotopes can provide a particularly useful tool for stratigraphic division and comparison at a global-scale. Due to the absent detailed zircon-age constraints, the carbon isotope composition of marine carbonate rocks have been an important tool for the Ediacaran stratigraphic division and comparison $[1,3,7]$. On the basis of detailed field work, in this study we provide the first and systematic discussion on the carbon and oxygen isotopic composition of the Neoproterozoic glacial carbonate cements in the Helan Mountain, North China. We also discussed the indications of these data on the Neoproterozoic paleogeographic and paleoclimate evolution in the Helan Mountain. In addition, no volcanic interlayers have been found in the study area before, thus no isotopic ages were ever reported, and the depositional age of this Neoproterozoic succession is still unknown. We presented the carbon and oxygen isotopic composition of the Sinian Zhengmuguan and Tuerkeng formations in the Helan Mountain, along with a comparison on the global-scale for the observed fossils in the Tuerkeng Formation, to confirm the depositional ages of these two formations. These studies provide new constraints on the depositional ages of the Zhengmuguan and Tuerkeng formations in the North China Block.

\section{Geological setting and the sampling area}

The Helan Mountain is located at the transition zone of be- tween Tarim-Sino Korean Block and the southern margin of the North China Block (Figure 1). It belongs to part of the west-east transition zone of the North China Block. The tectonic and deformation evolution history is relatively complex. Along with the widespread transgression in the North China Block during the Meso-Neoproterozoic, stable epicontinental deposits were well developed in the Helan Mountain, including the Changcheng, Jixian and Sinian systems, in an ascending order [24-26].

The Sinian sequence is separated from the underlying Wangquankou Formation of the Jixian system by an angular unconformity and disconformably contacted with the overlying Cambrian-aged Suyukou Formation, respectively. The sequence crops out mainly in the Jingdiquan-ZhenmuguanSuyukou area, Helan Mountain (Figure 1). The Sinian sequence comprises two formations from bottom to top: the Zhengmuguan Formation that is composed of tillite and the Tuerkeng Formation that is composed of grey-green fine sandstone and silty-slate. In this study, we focus on five sections of the Sinian sequence in the Helan Mountain, including (from north to south, Figure 1) Tuerkeng (PM025), Suyukou (PM026), Binggou (PM405), Peijianchang (PM1201) and Zihuagou (PM803) sections.

The total thickness of Sinian strata at Tuerkeng section is $101 \mathrm{~m}$, comprising the Zhengmuguan (91.2 m thick) and Tuerkeng formations (the top not seen, $1 \mathrm{~m}$ thick). The Zhengmuguan Formation consists of grey-whity thick-bedded morainic diamictites, with each monolayer of $50-140$ $\mathrm{cm}$ thicknees, unconformably overlying the Wangquankou Formation. The length of gravels of morainic diamictites is $0.2-40 \mathrm{~cm}$, composed predominantly of dolomites and quartz $(10 \%-30 \%)$. The dolomites are characteristic by microcrystal and rhythmical bedding. The Tuerkeng Formation conformably overlies the Zhengmuguan Formation, consisting of black-grey thin- and medium bedded sandy slate. Parts of them are colorated by iron oxides. Besides, abundant macro-body fossils are well preserved in this formation.

The Suyukou section is more than $163 \mathrm{~m}$ thick (Figure 2(a)), including the Zhengmuguan $(25 \mathrm{~m})$ and Tuerkeng formations $(130 \mathrm{~m})$. The lithologies of the Zhengmuguan Formation are briefly described as (1) light grey thickbedded moraine diamictites (Figure 2(b)), with mixed gravelly sandy dolomicrite (Sample 026-27); (2) moraine diamictites containing gravel microcrystalline structure and comprising 5\% clasts, $35 \%$ sand and $60 \%$ cements (basal cementation type); (3) the clasts are mainly chert, dolomite and quartz, and the cements are composed of dolomicrite and little quartz; and (4) the indentation, nick and stria are present on some clasts of the moraine diamictites. In particular, we found a glacial valley at the contact zone between the Zhengmuguan and Wangquankou formations. The erosion depth and level of line-sight of the glacial valley are 40 and $150 \mathrm{~m}$, respectively, and it was filled with Zhengmuguan diamictites. On the top of the Suyukou section, 


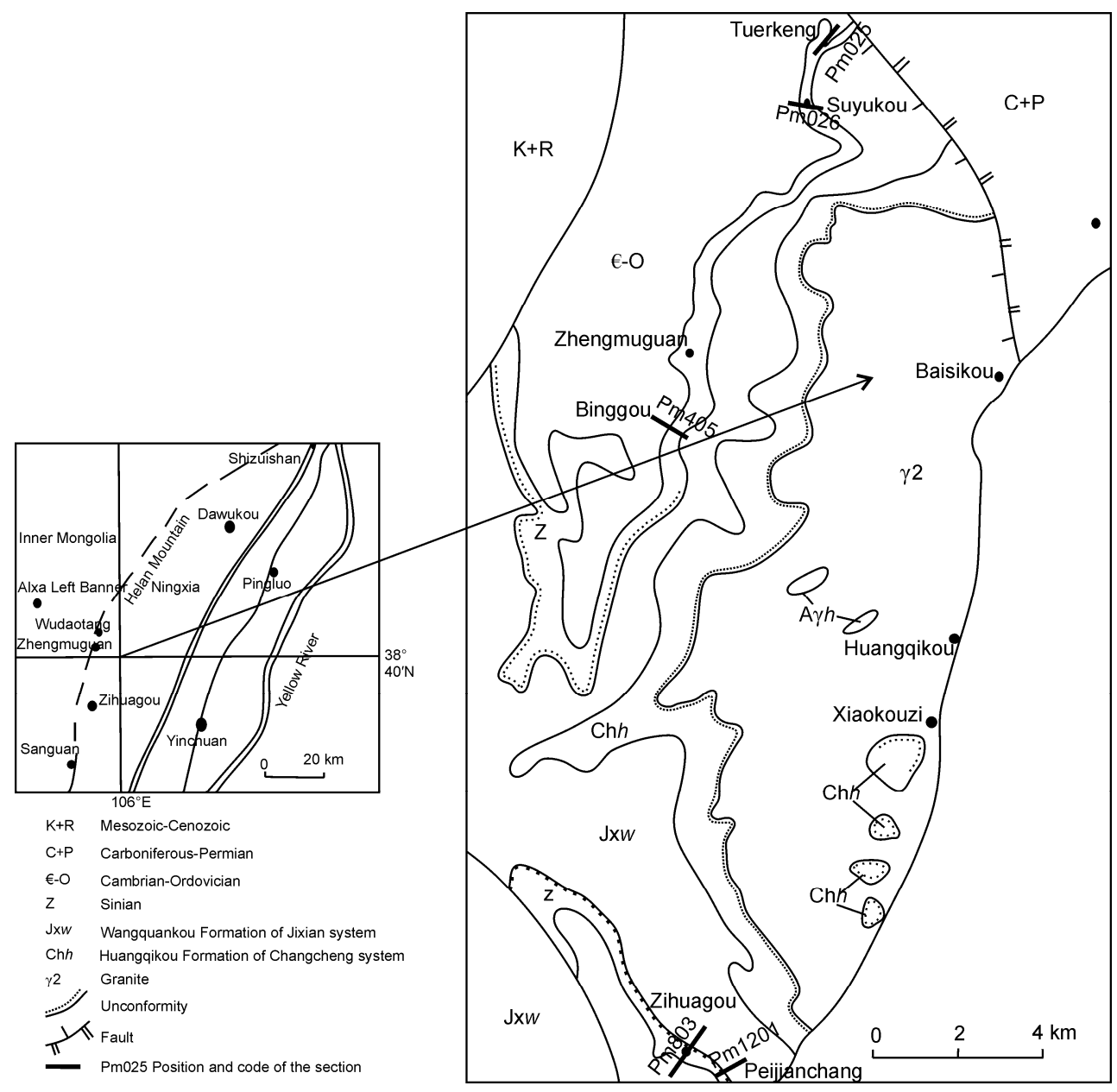

Figure 1 The Sinian sections in the Helan Mountain, Ningxia, North China.

the Tuerkeng Formation is conformable with Zhengmuguan Formation, containing a suit of light green-grey silty-slate (Figure 2(c)).

The Binggou section is $245 \mathrm{~m}$ thick and consists of Zhengmuguan $(86.2 \mathrm{~m})$ and Tuerkeng formations $(121 \mathrm{~m})$. The Zhengmuguan Formation is composed of light-colored to flesh-reddish complex moraine diamictites, with each layer about $60-300 \mathrm{~cm}$ thick. The clasts $(70 \%$ of the total contents) have an average gravel size of 3-6 cm and composed predominantly of dolomite, limestone, little quartz and chert. Meanwhile, the cements are calcareous and show basal cementation. Some coarse to huge conglomerates are also observed in this formation and become smaller along the succession downward. On the top of the section, the Tuerkeng Formation consists of grey-green silty-slate with pyrites (which have been ferritization) and a mass of fossils.

The 37-m-thick Peijianchang section contains the Zhengmuguan $(11.1 \mathrm{~m})$ and Tuerkeng formations (the top younger layers are not seen, $8 \mathrm{~m}$ ). On the bottom of the section, the Wangquankou Formation consists of light-grey thickbedded chert-dolomite and unconformably contacted with the overlying Zhengmuguan Formation. The lower part of the Zhengmuguan Formation shows similar characteristics with those of other sections. Particularly notable for the top of the Zhengmuguan Formation, the sixth and seventh layers of dolomites (Figure 3(a)) have a total thickness of 140 $\mathrm{cm}$. The dolomite succession contains no conglomerate, strongly different from those of other sections. The sixth layer dolomicrites are defined as laminated dolomites in the field (Figure 3(a)) and fine-grained quartz sandstone dolomicrites with sandy crystallite structure (sample 1201-6-1, by microscope (Figure 3(b)). The sand grains comprise mainly monocrystalline quartz (45\%) and dolomite cements $(55 \%)$ with major basal cementation (part with interstice cementation). The seventh layer dolomites are named thick-bedded dolomite in the field (Figure 3(a)), and are defined as dolomicrites by microscope (sample 1201-7-15). The dolomicrite, with microcrystalline structure (Figure $3(c)$ ), contains more than $95 \%$ microcrystalline dolomite, with little inhomogeneous distribution quartz.

The Zihuagou section, with a total thickness of $22 \mathrm{~m}$, comprises the Zhengmuguang (the base not seen, $3 \mathrm{~m}$ ) and Tuerkeng formations $(11 \mathrm{~m})$. The Zhengmuguan Formation shows similar petrological characteristics with those of the 


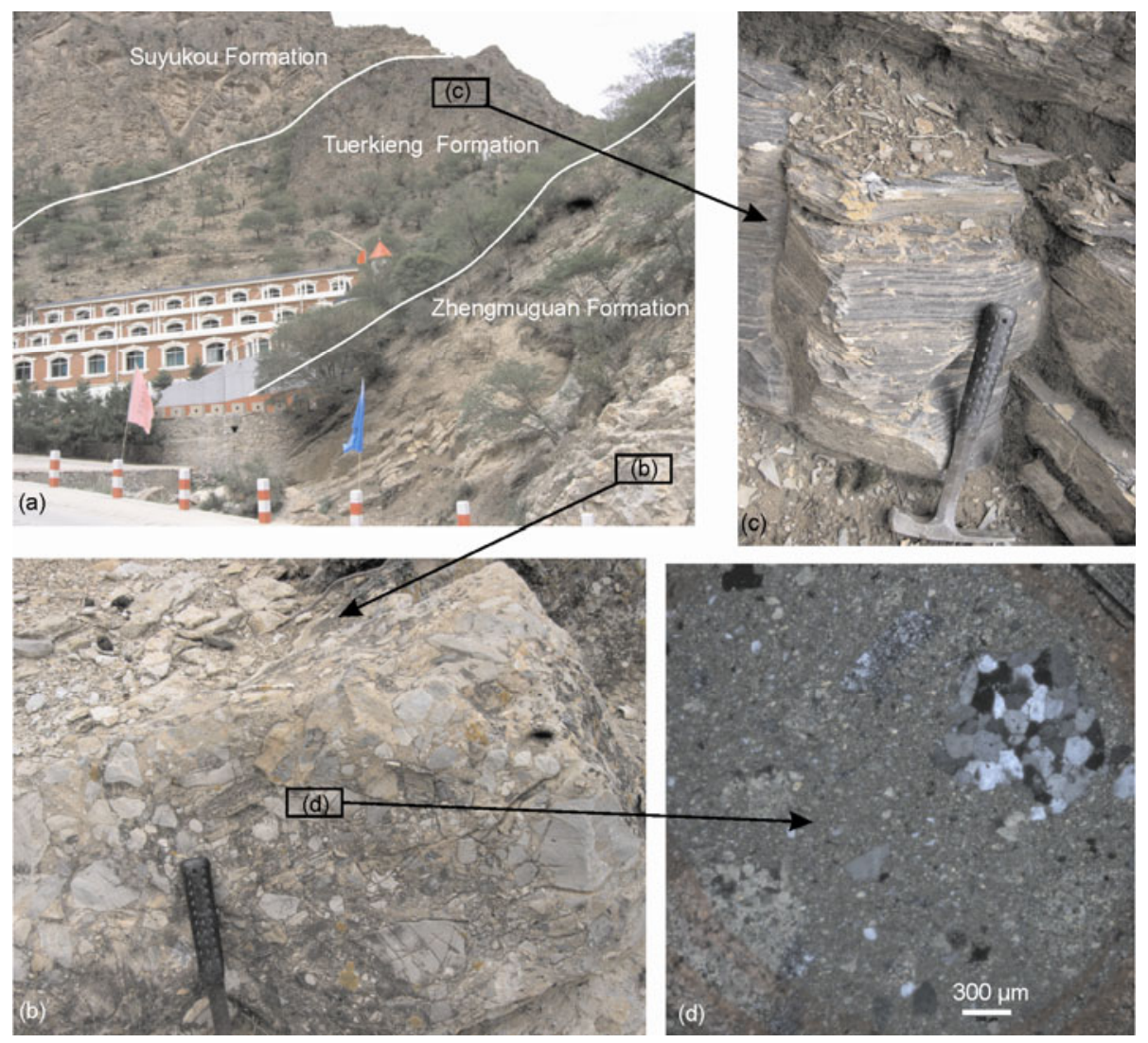

Figure 2 The field and micro-structure photographs of the Suyukou section. (a) The integral photograph of the Suyukou section; (b) the white-grey thick-bedded moraine anagenite of the Zhengmuguan Formation; (c) the black-grey thin-bedded sandy-slate of the Tuerkeng Formation; (d) the micro-structure of mixed gravel and sand dolomicrite of the Zhengmuguan Formation.

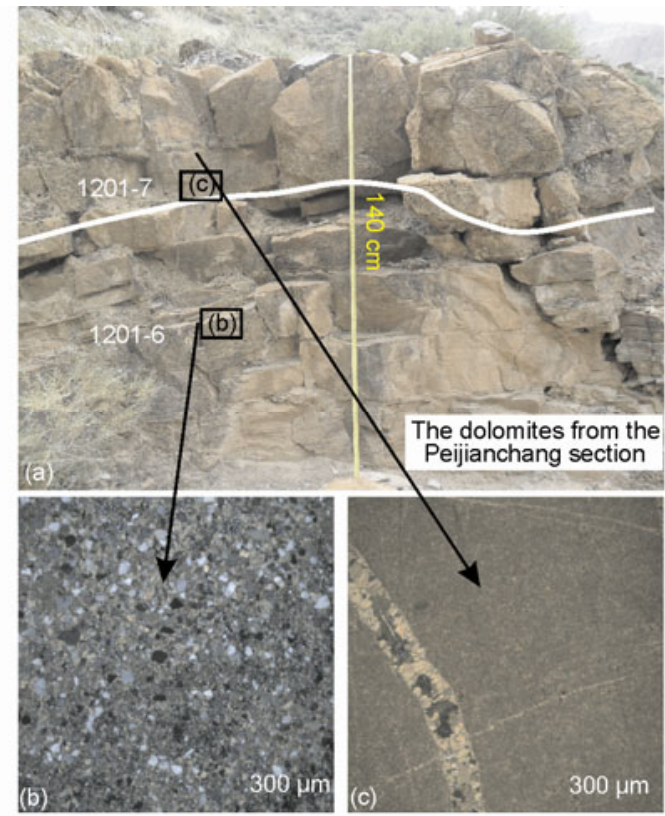

Figure 3 Field photographs and microstructure of the dolomites from the Peijianchang section. (a) Laminated dolomite of the sixth layer and the thick-bedded dolomite of the seventh layer of the Zhengmuguan Formation; (b) microstructure of the fine quartz sandstone dolomicrite from the sixth layer of the Zhengmuguan Formation, cross-polarized light; (c) microstructure of the dolomicrite from the seventh layer of the Zhengmuguan Formation, cross-polarized light. other sections, consisting of yellow-purple thick-bedded conglomerates. The Zhengmuguan Formation is overlain by the Tuerkeng Formation which contains purple mud-silty dolomites and "vermicule" macro body fossil are preserved in the Tuerkeng Formation.

\section{Analysis methods and results}

\subsection{Methodology}

A total of 158 fresh limestone and dolomite samples (avoiding fractures, calcite veins and post depositional alterations) were collected by equal intervals from the measured five sections of Sinian carbonates in the Helan Mountain. We chose 113 samples among them for carbon and oxygen isotopes analyses after microscope identification. Based on the petrographic observation, the whole-rock samples from the Tuerkeng, Binggou and Zihuagou sections are crushed without pollution to less than 200 meshes for isotopic analysis. Samples from the Suyukou and Peijianchang sections were made into thin sections $(0.1-0.5$ $\mathrm{mm}$ thick) and 200-300 $\mu \mathrm{g}$ cements of the samples were used for isotopic analyses.

The carbon and oxygen isotopic analyses of the Tuerkeng, Binggou and Zihuagou sections samples were measured on 
Finnigan MAT 253 IRMS (isotope ratio mass spectrometer) at the State Key Laboratory of Geological Processes and Mineral Resources, China University of Geosciences (Wuhan). The geochemical analysis for the Suyukou and Peijianchang sections samples were run on the Continuous and Stable Isotope Mass Spectrometer CF-IRMS at Guangzhou Institute of Geochemistry, Chinese Academy of Sciences. The processes of the isotopic analyses are described as follows: firstly, $0.2 \mathrm{mg}$ samples were taken into round base glass bottle and pinned to the bottle, then high purity $\mathrm{He}$ blown into the bottle; secondly, 5-6 drops of $100 \% \mathrm{H}_{3} \mathrm{PO}_{4}$ dropped into the bottle and pinned again to the bottle after the balance for more than $6 \mathrm{~h}$ at $90^{\circ} \mathrm{C}$; finally, the generated $\mathrm{CO}_{2}$ was led to the Sample Loop, chromatographic column separation $\left(90^{\circ} \mathrm{C}\right.$, Poraplot Q, $25 \mathrm{~m} \times 0.32 \mathrm{~mm}$, Varian Ltd, Netherlands) and Nafion drying were conducted, then the $\mathrm{CO}_{2}$ gas was measured for carbon and oxygen isotopic composition analyses on the Mass Spectrometer. National standard GBW04405 and international standards IAEACO-8 and NBS19 were used for correcting the isotope values. Isotopic composition is reported in standard delta notation, where $\delta$ (in \%o $)=\left[\left(R_{\text {sample }}-R_{\text {standard }}\right) / R_{\text {standard }}\right] \times 1000$, relative to the VPDB (Vienna Pee Dee Belemnite) standard. Precisions for the $\delta^{13} \mathrm{C}$ and $\delta^{18} \mathrm{O}$ values are better than $0.1 \%$. The external accuracy of the carbon and oxygen isotopes are $<0.15 \%$ and $<0.2 \%$ [27] relative to the VPDB.

The post depositional alteration and diagenetic overprinting of original seawater isotopic signatures are always concerns in analyzing the carbon and oxygen isotopes for ancient carbonates. The carbon and oxygen isotopic composition of carbonate rocks is very sensitive to the postdepositional alteration. If isotope exchanges have taken place among atmosphere, hydrothermal solution and carbonates, the $\delta^{18} \mathrm{O}$ values of the carbonates will deviate from the normal values. In general, carbonates have suffered the post-depositional alteration if they contain $\delta^{18} \mathrm{O}$ values lower than $-5 \%$ (PDB) but their $\delta^{13} \mathrm{C}$ composition and content are probably not affected. Besides, if $\delta^{18} \mathrm{O}$ values are lower than $-10 \%$, the carbonates must have been eroded strongly by the post-depositional alteration, and within weak reliability [1]. On the other hand, a positive correlation between $\delta^{13} \mathrm{C}$ and $\delta^{18} \mathrm{O}$ for carbonates generally means that the carbonates have been affected by diagenesis [1,28]. All the 113 samples in this study have $\delta^{18} \mathrm{O}$ values between $-10 \%$ and $0 \%$ with an average value of $-8.4 \%$, indicating an original $\delta^{13} \mathrm{C}$ signature of seawater. The correlation coefficients between $\delta^{13} \mathrm{C}$ and $\delta^{18} \mathrm{O}$ data of the Tuerkeng, Suyukou and Peijianchang sections are $0.29,0.27$ and 0.1 , respectively, suggesting that post-depositional fluid flow and associated organic diagenesis likely have not taken strong influence on the carbon composition of these carbonates. Five samples of the Tuerkeng Formation from the Zihuagou section have correlation coefficient of 0.78 between $\delta^{13} \mathrm{C}$ and $\delta^{18} \mathrm{O}$, indicating strong alterations by post-depositional diagenesis (not discussed in this paper).

\subsection{Results}

A total of 113 carbonate samples were obtained from measured sections of the Sinian succession for carbon and oxygen isotopes analyses. Carbonates from the Suyukou (50 samples) and Peijianchang (46 samples) sections were studied with a high-resolution. The Tuerkeng, Binggou and $\mathrm{Zi}$ huagou sections were used as comparative sections. The carbon and oxygen isotopes data are available in Table 1 and the $\delta^{13} \mathrm{C}$ curves are shown in Figure 4.

At the Tuerkeng section, only one sample was analyzed from the Wangquankou Formation, with $\delta^{13} \mathrm{C}$ value of $-0.45 \%$. Samples from the Zhengmuguan Formation show a continuous decline in $\delta^{13} \mathrm{C}$ values from $-0.84 \%$ (base) to $-2.18 \%$ (top) (Figure 4). Carbonate samples from the first four layers on the bottom of the Zhengmuguan Formation show a continuous decline in $\delta^{13} \mathrm{C}$ values from $-0.8 \%$ (the first layer) to the lower cycle minimum $\delta^{13} \mathrm{C}$ value of $-1.31 \%$ o (the fourth layer), above this, an anomaly positive excursion reaching $-0.12 \%$ (with a slight variation, Figure 4). On the upper part of the Zhengmuguan Formation, the values gradually decline and drop to the minimum $\delta^{13} \mathrm{C}$ value of $-2.18 \%$ of the section. At last, the $\delta^{13} \mathrm{C}$ values keep constant at $-2.02 \%$ after a bigger negative excursion occurs on the top of the Zhengmuguan Formation (Figure 4, Table 1).

The Suyukou section received the detailed study herein. Within the 24.5-m-thick succession, a total of 50 samples were collected by equal intervals for $\delta^{13} \mathrm{C}$ analyses. The $\delta^{13} \mathrm{C}$ values gradually decline from bottom to top, similar to the patterns observed in the Tuerkeng Sinian carbonates succession, whereas the Suyukou section samples exhibit much bigger excursion amplitudes. The $\delta^{13} \mathrm{C}$ value of the one sample from the Wangquankou Formation is $-1.13 \%$. The $\delta^{13} \mathrm{C}$ values of the Zhengmuguan Formation decline sharply from the base $(0.11 \%$ ) to the top $(-6.88 \%$ ) (Figure 4 , Table 1), which are arranged in a series of alternating positive and negative excursions (such as negative excursion around $-2.5 \%$ on the seventh layer and positive excursion around $0.52 \%$ on the twenty-first layer) (Figure 4). The $\delta^{13} \mathrm{C}$ values reach its biggest positive values of $0.52 \%$ o of this section at the twenty-first layer. After this, $\delta^{13} \mathrm{C}$ values gradually decline and the most negative excursion occur at the forty-sixth layer of $-6.88 \%$, and then decline with smaller oscillation to $-3.19 \%$ on the top of the Zhengmuguan Formation (Figure 4).

The variation of carbon isotopic composition of the Zhengmuguan Formation, Pejianchang section is similar to that observed from the Tuerkeng and Suyukou sections, with $\delta^{13} \mathrm{C}$ values down to $-4.72 \%$ in the top from $-1.04 \%$ o at the base (Figure 4). One sample from the Wangquankou Formation gives $\delta^{13} \mathrm{C}$ values of $-1.10 \%$. Samples from the base of the Zhengmuguan Formation have $\delta^{13} \mathrm{C}$ values near $-1.04 \%$ o, and then decline to $-1.10 \%$ (Figure 4 , Table 1). It is similar to the patterns observed from the Suyukou section 
Table 1 The carbon and oxygen isotopes data of the Sinian carbonates in the Helan Mountain

\begin{tabular}{|c|c|c|c|c|c|}
\hline Stratigraphy ${ }^{\text {a) }}$ & Sample & Thickness $^{\text {b) }}(\mathrm{m})$ & Petrology & $\delta^{13} \mathrm{C}(\%, \mathrm{VPDB})$ & $\delta^{18} \mathrm{O}(\% \circ, \mathrm{VPDB})$ \\
\hline \multicolumn{6}{|l|}{ Tuerkeng section } \\
\hline $\mathrm{J}_{\mathrm{x}} w$ & $025-1$ & 3.4 & pelsparite & -0.45 & -6.10 \\
\hline $\mathrm{Z}_{2} z$ & $025-2$ & 9.4 & micrite & -0.84 & -6.71 \\
\hline $\mathrm{Z}_{2} z$ & $025-3$ & 12.8 & micrite & -0.94 & -5.73 \\
\hline $\mathrm{Z}_{2} z$ & $025-4$ & 24.0 & micrite & -1.31 & -5.10 \\
\hline $\mathrm{Z}_{2} \mathrm{Z}$ & $025-5$ & 28.5 & micrite & -0.12 & -7.82 \\
\hline $\mathrm{Z}_{2} z$ & $025-7$ & 57.5 & dolomicrite & -0.79 & -7.70 \\
\hline $\mathrm{Z}_{2} z$ & $025-8$ & 59.1 & micrite & -2.18 & -6.35 \\
\hline $\mathrm{Z}_{2} z$ & $025-9$ & 61.4 & micrite & -2.02 & -6.91 \\
\hline \multicolumn{6}{|l|}{ Suyukou section } \\
\hline $\mathrm{J}_{\mathrm{x}} w$ & $026-0$ & 0.0 & micrite & -1.13 & -6.75 \\
\hline $\mathrm{Z}_{2} z$ & 026-1 & 0.5 & micrite & 0.11 & -6.60 \\
\hline $\mathrm{Z}_{2} z$ & $026-2$ & 1.0 & micrite & -0.22 & -4.89 \\
\hline $\mathrm{Z}_{2} z$ & 026-3 & 1.5 & micrite & -0.29 & -5.16 \\
\hline $\mathrm{Z}_{2} z$ & $026-4$ & 2.0 & micrite & -0.34 & -7.27 \\
\hline $\mathrm{Z}_{2} z$ & $026-6$ & 3.0 & micrite & -0.10 & -6.13 \\
\hline $\mathrm{Z}_{2} z$ & $026-7$ & 3.5 & micrite & -2.56 & -7.54 \\
\hline $\mathrm{Z}_{2} z$ & $026-8$ & 4.0 & micrite & -0.81 & -7.68 \\
\hline $\mathrm{Z}_{2} z$ & $026-9$ & 4.5 & micrite & 0.02 & -6.82 \\
\hline $\mathrm{Z}_{2} z$ & 026-10 & 5.0 & micrite & -0.58 & -5.99 \\
\hline $\mathrm{Z}_{2} z$ & 026-11 & 5.5 & micrite & -1.04 & -6.64 \\
\hline $\mathrm{Z}_{2} z$ & 026-12 & 6.0 & micrite & -0.22 & -7.90 \\
\hline $\mathrm{Z}_{2} z$ & 026-13 & 6.5 & micrite & -0.43 & -7.72 \\
\hline $\mathrm{Z}_{2} z$ & 026-14 & 7.0 & micrite & -0.18 & -7.74 \\
\hline $\mathrm{Z}_{2} z$ & 026-15 & 7.5 & micrite & -0.10 & -5.87 \\
\hline $\mathrm{Z}_{2} z$ & 026-16 & 8.0 & micrite & -0.12 & -5.89 \\
\hline $\mathrm{Z}_{2} z$ & 026-17 & 8.5 & micrite & -0.16 & -8.23 \\
\hline $\mathrm{Z}_{2} z$ & 026-18 & 9.0 & micrite & -0.21 & -8.19 \\
\hline $\mathrm{Z}_{2} z$ & 026-19 & 9.5 & micrite & -0.72 & -10.48 \\
\hline $\mathrm{Z}_{2} z$ & 026-22 & 11.0 & micrite & -0.21 & -8.05 \\
\hline $\mathrm{Z}_{2} z$ & $026-23$ & 11.5 & micrite & -0.28 & -8.05 \\
\hline $\mathrm{Z}_{2} z$ & 026-24 & 12.0 & micrite & -0.26 & -7.83 \\
\hline $\mathrm{Z}_{2} z$ & 026-25 & 12.5 & micrite & -0.32 & -8.05 \\
\hline $\mathrm{Z}_{2} z$ & 026-26 & 13.0 & micrite & -0.88 & -5.76 \\
\hline $\mathrm{Z}_{2} z$ & $026-27$ & 13.5 & micrite & -0.42 & -7.19 \\
\hline $\mathrm{Z}_{2} z$ & 026-28 & 14.0 & micrite & -1.14 & -9.02 \\
\hline $\mathrm{Z}_{2} z$ & 026-29 & 14.5 & micrite & -0.51 & -8.11 \\
\hline $\mathrm{Z}_{2} z$ & 026-30 & 15.0 & micrite & -0.43 & -7.97 \\
\hline $\mathrm{Z}_{2} z$ & 026-31 & 15.5 & micrite & -0.63 & -7.78 \\
\hline $\mathrm{Z}_{2} z$ & 026-32 & 16.0 & micrite & -0.97 & -8.42 \\
\hline $\mathrm{Z}_{2} z$ & 026-33 & 16.5 & micrite & -0.75 & -7.04 \\
\hline $\mathrm{Z}_{2} z$ & 026-34 & 17.0 & micrite & -1.15 & -4.65 \\
\hline $\mathrm{Z}_{2} z$ & 026-35 & 17.5 & micrite & -2.81 & -8.19 \\
\hline $\mathrm{Z}_{2} z$ & 026-36 & 18.0 & micrite & -1.20 & -8.21 \\
\hline $\mathrm{Z}_{2} z$ & 026-37 & 18.5 & micrite & -2.79 & -7.94 \\
\hline $\mathrm{Z}_{2} z$ & 026-38 & 19.0 & micrite & 0.16 & -7.13 \\
\hline $\mathrm{Z}_{2} z$ & 026-39 & 19.5 & micrite & -0.05 & -6.74 \\
\hline $\mathrm{Z}_{2} z$ & $026-40$ & 20.0 & micrite & -1.51 & -8.40 \\
\hline $\mathrm{Z}_{2} z$ & $026-41$ & 20.5 & micrite & -2.67 & -19.79 \\
\hline $\mathrm{Z}_{2} z$ & $026-42$ & 21.0 & micrite & -1.83 & -8.26 \\
\hline $\mathrm{Z}_{2} z$ & $026-43$ & 21.5 & micrite & -1.42 & -8.10 \\
\hline $\mathrm{Z}_{2} z$ & 026-44 & 22.0 & micrite & -1.10 & -5.85 \\
\hline $\mathrm{Z}_{2} z$ & 026-45 & 22.5 & micrite & -2.81 & -6.79 \\
\hline $\mathrm{Z}_{2} z$ & $026-46$ & 23.0 & micrite & -6.88 & -7.14 \\
\hline $\mathrm{Z}_{2} z$ & $026-47$ & 23.5 & micrite & -1.04 & -7.02 \\
\hline $\mathrm{Z}_{2} z$ & $026-48$ & 24.0 & micrite & -3.45 & -8.11 \\
\hline $\mathrm{Z}_{2} z$ & $026-49$ & 24.5 & micrite & -3.19 & -12.85 \\
\hline
\end{tabular}




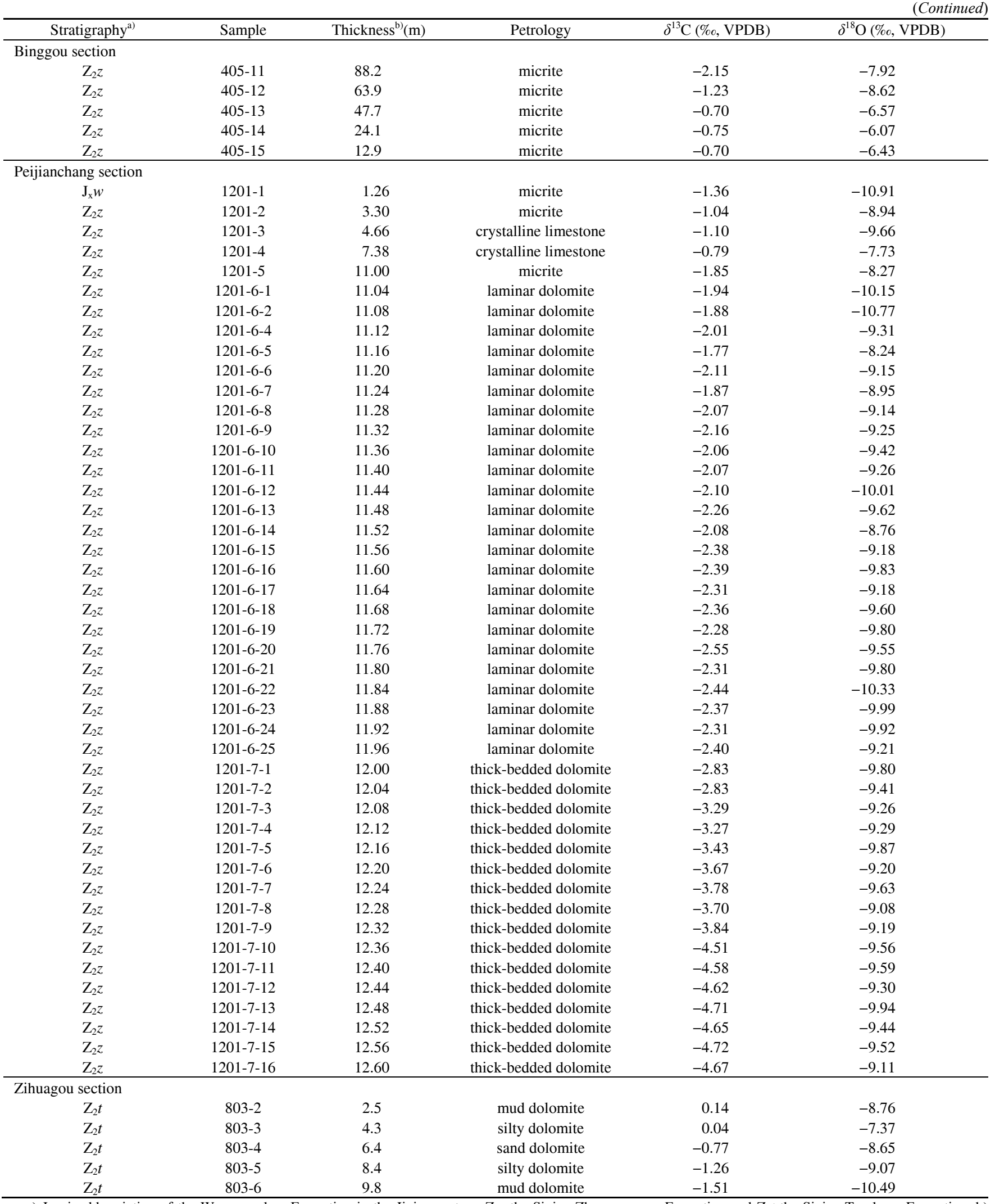

a) $\mathrm{J}_{\mathrm{x}} w$ is abbreviation of the Wangquankou Formation in the Jixian system, $Z_{2} z$ the Sinian Zhengmuguan Formation and $Z_{2} t$ the Sinian Tuerkeng Formation. b) Strata thickness. The sample number was sequenced from base to top of the section. Samples from the Tuerkeng, Binggou and Zihuagou sections are measured on a Finnigan MAT 253 IRMS at the State Key Laboratory of Geological Processes and Mineral Resources, China University of Geosciences (Wuhan). The geochemical analysis for the Suyukou and Peijianchang sections samples are measured on the Continuous and Stable Isotope Mass Spectrometer CF-IRMS at the Guangzhou Institute of Geochemistry, Chinese Academy of Sciences. National standard GBW04405 and international standards IAEA-CO-8 and NBS19 are used for correcting the isotopes. The external accuracy of the carbon and oxygen isotopes are $<0.15 \%$ and $<0.2 \%$ [27] relative to the VPDB. 


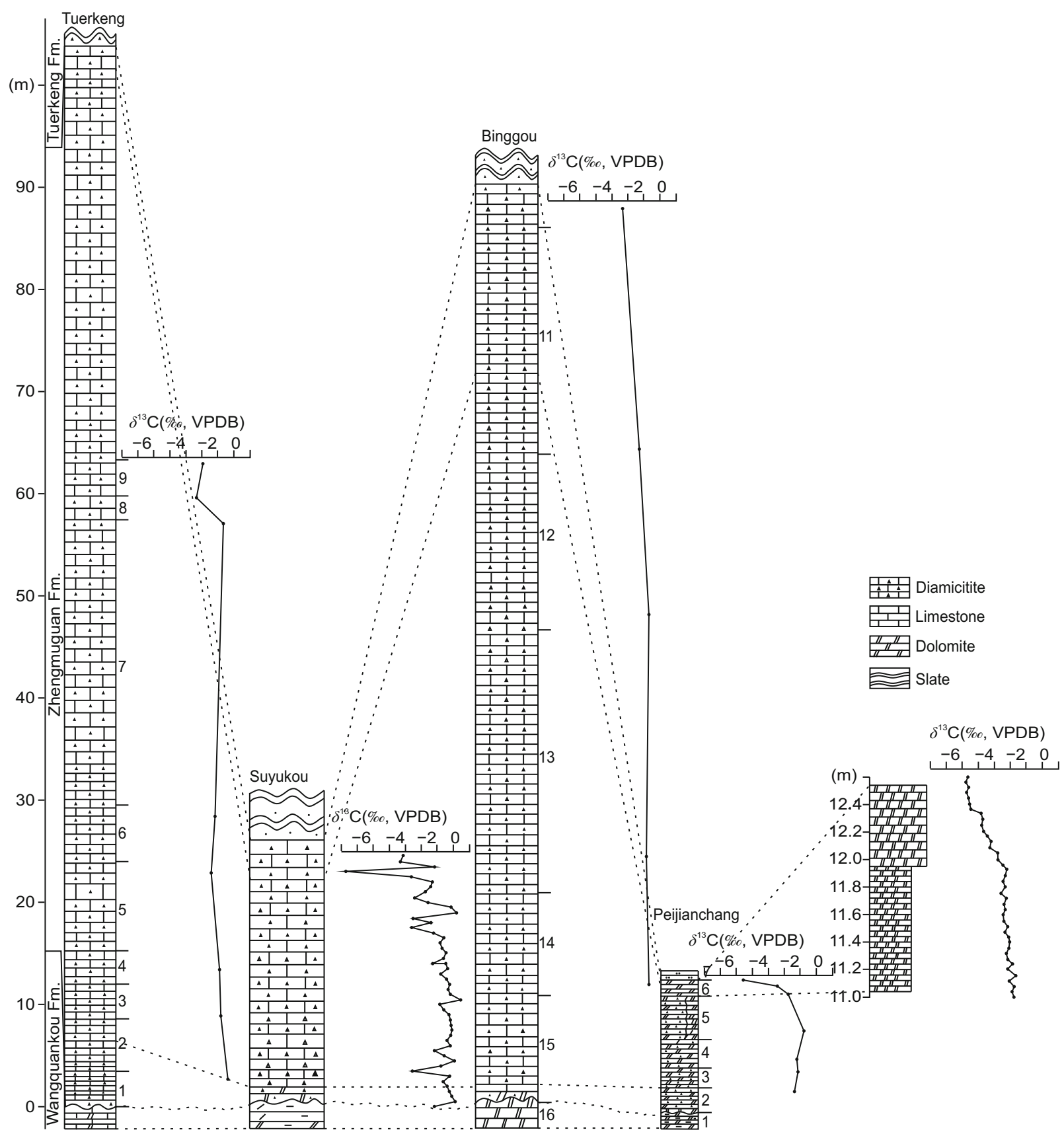

Figure 4 Secular variations in $\delta^{13} \mathrm{C}$ values versus stratigraphic depth $(\mathrm{m})$ for the Sinian carbonates in the Helan Mountain. The dotted lines represent comparable different sections, the sixth and seventh layers dolomites of the Peijianchang section have different plotting scales from other sections (marked on the diagram). Isotope data of the Zihuagou section have not been discussed.

as they both have a smaller positive excursion and then the $\delta^{13} \mathrm{C}$ values gradually drop to the lowest value of $-4.72 \%$ o (Figure 4). Notably, two layers dominated by breccia limestones from the top of the Zhengmuguan Formation turn into lamellar and thick-bedded dolomites. We performed a higher resolution carbon and oxygen isotopes analyses for these two layers of dolomites with a higher sampling density. The 41 samples from the $1.4-\mathrm{m}$-thick layer were collected and they had a consistent variation of $\delta^{13} \mathrm{C}$ values from base $(-0.79 \%$ ) to top $(-4.72 \%$ ) with no significant oscillation (Figure 4).

Setting the Binggou section as a comparison basis, we selected five carbonate samples from the Zhengmuguan Formation to compare with other sections. The carbon isotope values of this section record the lowest degree of $\delta^{13} \mathrm{C}$ values, which vary from $-0.70 \%$ at the base of this formation to $-2.15 \%$ on the top with an average value of $-1.11 \%$. This value lies within the same range as that of the other sections.

The mud and silty dolomites from the Tuerkeng For- 
mation of the Zihuagou section have higher $\delta^{13} \mathrm{C}$ and $\delta^{18} \mathrm{O}$ correlation coefficients than those from other samples, which might have suffered stronger post-depositional and diagenesis processes. Therefore, these samples are not discussed in this study.

In summary, the $\delta^{13} \mathrm{C}$ values of the four sections exhibit a total range from $-6.88 \%$ o to $0.52 \%$, with obviously negative excursions concentrating between $-4.5 \%$ and $-0.5 \%$ in the middle-upper part of sections. All the $\delta^{13} \mathrm{C}$ values of the Zhengmuguan Formation samples from the four sections show a gradual decline from the base to top with the maximum and minimum $\delta^{13} \mathrm{C}$ values appear at the base and top, respectively. Although small anomaly positive and negative excursions occur within these values, they do not significantly affect the whole trend of $\delta^{13} \mathrm{C}$ curve.

\section{Fossils from the Tuerkeng Formation and implications for the age of the Sinian succession in the Helan Mountain}

A lot of "vermicular" macroscopic fossils were found in the silty-slates and dolomites of the Tuerkeng Formation from the Tuerkeng, Suyukou, Binggou and Zihuagou sections. The "vermicular" fossils are long ribbon-shaped, bilateral symmetry, with a width of $\sim 1-5 \mathrm{~mm}$ and some even up to $\sim 8 \mathrm{~mm}$. The length of the fossils is $\sim 10-80 \mathrm{~mm}$, with clear minuteness banding groove and rill (Figure 5). The fossils are distributed along the layers by circuitous distorted level. The fossils are widespread, stable output horizon and not restricted by lithofacies zones. They are mainly distributed at the upper part of the Tuerkeng Formation in the region. Besides the four sections in this study, the "vermicular" fossils are also found in the Zhengmuguangou, Alxa Left Banner, Inner Mongolia and Jingdiquan, Yinchuan City [21,24,26]. Zheng et al. [21] reported this kind of fossil from the Banyan Part of the Zhengmuguan Formation (present as Tuerkeng Formation) in the Helan Mountain as trace fossils Taenioichnus zhengmuguanensis, Helanoichnus helanensi, Parascalarituba ningxiaensis, Ningxiaichnus suykouensis, etc. and speculated that these fossils were formed by some bilaterally symmetrical floppy body vermes or other animals sporting or foraging along the layer surface. Futhermore, the "vermicular" body fossils Sabellidites found in the Sinian strata were proven to be such banding trace fossils [29]. Besides, Li et al. [30] showed that the Taenioichnus in the Sinian slates of the Helan Mountain should be classified into Shaanxilithes. The banding-liked Shaanxilithes structures are as well widespread in Huaning Huote, Xiangjiagou and Jingning Wangjiawan in eastern Yunnan [31], Zhoujieshan Formation, Quanji group of the northern margin of the Qaidam Basin [32-34], and Gaojiashan biogroup of the middleupper Gaojiashan section of the Dengying Formation in southern Shanxi [35,36]. By intensive study on the Shaanx- ilithes from the Taozichong Formation in Qinzhen, Guizhou Province, Hua et al. [31] proposed that the Shaanxilithes should be classified as algae fossil fragments but not trace fossil or vermes. Compared with the stable distributed Shaanxilithes in South Australian, South Shanxi and Yangtze Craton, the Shaanxilithes are now established as an important fossil remark in comparing the South China Sinian and the global Vendian successions [31]. Helanoichnus, Palaeopascichnus, Shaanxilithes and Horodyskia are also recognized in the Banyan Part of the Zhengmuguan Formation (present as Tuerkeng Formation), and Zhoujieshan Formation, Quanji group of the Qaidam Basin, Shen et al. $[32,33]$ considered them as series genetic body fossils but not trace fossils. Carbon and oxygen isotopic composition of carbonates from the Hongtiegou Formation (underlying the Zhoujieshan Formation) indicated that this formation deposited after the Gaskiers glaciation. As the Palaeopascichnus and Shaanxilithes were found in the middle Dengying Formation and the Late Ediacaran in southern China, the depositional age of the Zhengmuguan (present as Tuerleng Formation) and Zhoujieshan formations in the Qaidam Basin were constrained to be deposited in the Ediacaran period (Sinian). We have had an oral discussion with Dr. Zhu S M about this issue and suggest here that the so-called "vermicular" fossils in the Tuerkeng Formation in the Helan Mountain belong to Shaanxilithes, which are the same species with the fossils of the Dengying Formation of the Late Sinian in the Yangtze Craton. Through detailed microstructural and microchemical investigation for Shaanxilithes ningqiangensis by using paleontology and modern analytical techniques, Mike et al. [37] indicated that the individual fossil of Shaanxilithes ningqiangensis is unbranched, bent ribbons, incompletely ribbon edge, concentric stripe likeness stromatolites structure, individual overlapping each other but not crosscutting. These pieces are similar to primitive organisms and preserved like clay molds. All the morphological characteristics indicate that

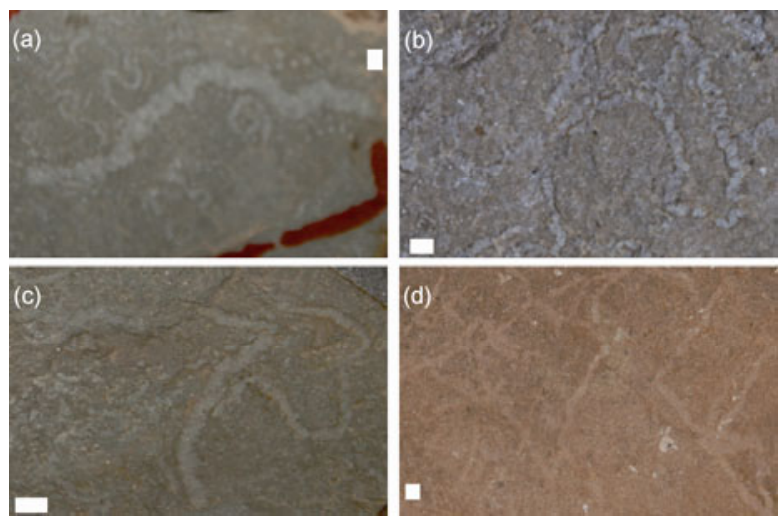

Figure 5 Fossils in the top layers of Tuerkeng Formation, Helan Mountain. (a)-(c) Marco-body fossils in the Suyukou slate; (d) marco-body fossils in the Zihuagou section dolomites. The white line stand for plotting scale of $2 \mathrm{~mm}$, and the photographs were taken in the Helan Mountain. 
these "vermicular" fossils are body fossils but not trace fossils [37]. Therefore, the "vermicular" marco-body fossils in the Tuerkeng Formation are similar to those observed from the Dengying Formation in South China, thus paleontology fossil evidence indicates that the depositional age for the Zhengmuguan and Tuerkeng formations is in the Sinian.

\section{Discussion}

On the basis of stratigraphic age, petrological and isotopic geochemical composition, the Neoproterozoic-aged glacial events are divided into four glacial epochs: Kaigas glaciation (751-741 Ma), Sturtian glaciation (718-660 Ma), Marinoan glaciation (651-635 Ma) and Gaskiers glaciation (583.7-582.1 Ma) [1,7,10,17,38,39]. Glacial deposits of Sturtian and Marinoan ages occur as global-scale and are widespread all over the world whereas the Kaigas and Gaskiers glaciations-aged glacial deposits are only distributed in limited regions [11,38]. Although the glacial deposit of Gaskiers age is a regional glacial event in the Neoproterozoic, it has significant impacts on the global climate changes and biological evolution during this period. The Gaskiers glaciation mainly occurred as moumtain glacier, which might have formed as ice sheet in some small basins with limited spatial distribution $[6,7,38]$. The typical Gaskiers glaciations-aged deposits are preserved in the eastern Newfoundland [12], northern Norway [13], and southern Oman [40]. Three remarkable $\delta^{13} \mathrm{C}$ negative excursions occurred in the Ediacaran (Sinian) period. They occurred after the Marinoan glaciation, after the Gaskiers glaciation, and the boundary of the Ediacaran and Cambrian, respectively [38]. The carbonates $\delta^{13} \mathrm{C}$ values of the upper part of the four sections in the Helan Mountain all exhibit a remarkably negative excursion from $-4.5 \%$ o to $-0.5 \%$, with the maximum negative excursion dropping to $-6.88 \%$. These features of the negative excursions are consistent with those of the carbon isotope negative excursions of the post-Gaskiers glaciation deposits in the word [14,16,47-49,54]. Combined with the petrological characteristics and regional comparisons, we propose that the glacial deposits in the Helan Mountain might represent a glacial deposit after Gaskiers glaciation in the North China Block.

Due to poor $\mathrm{U}-\mathrm{Pb}$ age constraints available for the postMarinoam glaciation, a comparison among global-scale glacial deposits for the post-Marinoam glaciation event is very difficult. The carbon and oxygen isotopes for carbonates are generally used to restrict the time of glaciations and compare glaciation events at a global-scale. In this study, the isotopes age data for the Zhengmuguan Formation glacial deposits are also absent. We therefore took $\delta^{13} \mathrm{C}$ and $\delta^{18} \mathrm{O}$ values to compare with those reported from coeval post-Gaskiers glaciations sedimentary strata in the world (Figure 6). The SHRIMP U-Pb zircon age of the Hankalchough Formation in the Quruqtagh area, Tarim
Block are $615 \pm 6 \mathrm{Ma}-542 \mathrm{Ma}[14,41,42]$. The $615 \mathrm{Ma}$ age is derived from the top of the Zhamoketi Formation, which is separated from the Hankalchough Formation by the Kenggou and Shuiquan formations [14,41,42]. Because of the conformable contact between the Hankalchough Formation and the overlying Cambrian Xishanbulake Formation, the Hankalchough Formation must be deposited prior to $615 \mathrm{Ma}$ and probably close to $542 \mathrm{Ma}$. Moreover, Zhu and Wang [43] also proposed that the depositional age of this glacial deposit is after Gaskiers glaciation and probably earlier than $551 \mathrm{Ma}$ [44]. The $\delta^{13} \mathrm{C}$ values for carbonates of the Hankalchough Formation range from $-0.2 \%$ o to $-17.1 \%$ and mainly concentrate within $-1.2 \%$ to $-12.3 \%$ o [14,45], which are similar to the carbon isotopic composition patterns found in our result (Figure 6). Moreover, the Luoquan Formation of the Luoquan glaciation on the southern margin of North China Block has previously been studied and proved that it could be comparable with the Zhengmuguan, Hankalchough and Hongtiegou formations in age $[16,21,24,33,46]$. The carbon and oxygen isotopic composition of the Sinian dolomites in the Ruzhou and Lushan area, Henan Province range from $-4.97 \%$ to $-0.95 \%$ [ [16] and the data-point distribution is close to our data (Figure 6).

The regional post-Gaskiers glaciation deposits are also reported in other places of the world. Prave et al. [47-49] conducted mass geochemistry study on the Neoproterozoic Aalradian group in Scotland and Ireland, and detailedly analyzed three depositional events of them which related to

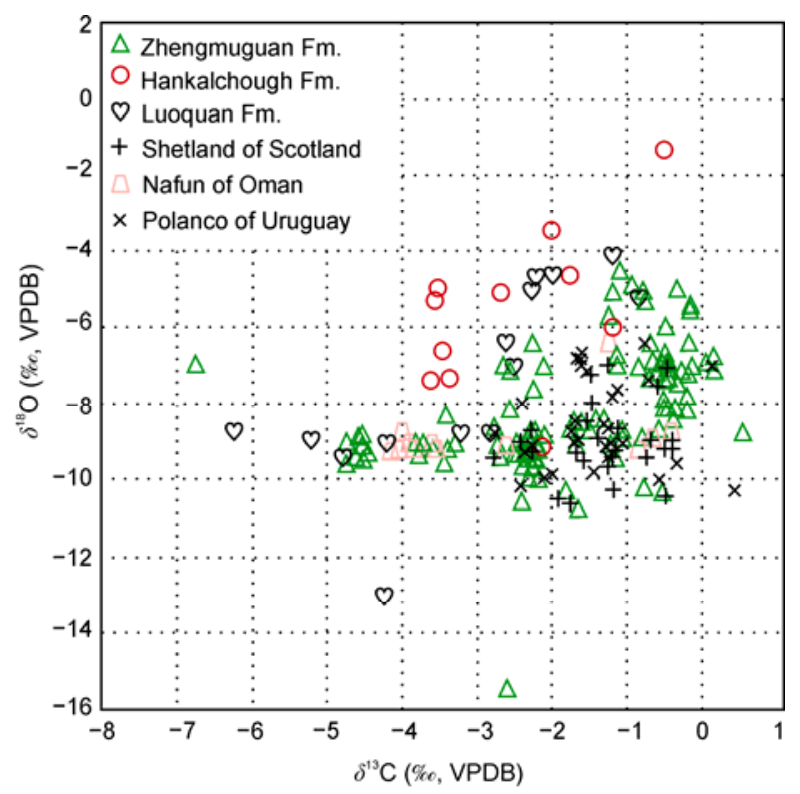

Figure 6 Carbon and oxygen isotopic composition comparison among global coeval deposits and Zhengmuguan Formation in the Helan Mountain. The Zhengmuguan Formation data are from this study, Hankalchough Formation data are from Xu et al. [14], Luoquan Formation data are from Zhang et al. [16], Shetland of Scotland data are from Prave [47-49], Nafun Formation data of Oman are from Guerrou et al. [39], Polanco limestones data of Uruguay are from Natlie et al. [54]. 
the great environment change. The post-Gaskiers glaciation deposits (600-551Ma) among of the Prave et al.'s studies [47-49] are consistent with that of the Suyukou section as the $\delta^{13} \mathrm{C}$ values for carbonates range from $-2.9 \%$ to $-0.5 \%$ o (Suyukou, $-2.79 \%$ o to $-0.1 \%$ ) and similar point distribution as shown in Figure 6. The $\delta^{13} \mathrm{C}$ values for carbonates of the top Sharan, Hugf subgroup, Nafun group (U-Pb age of $574 \pm 5 \mathrm{Ma}$ [40]) at southern Oman range from $-7.73 \%$ to $4.5 \%$ [39], which have a larger value range than that observed in this study, whereas the proportion of both ends of the Sharan data is not high and mostly centralizes from $-4.16 \%$ o to $-0.71 \%$ o. We chose part of their data for comparing with ours. The results show a similar distribution pattern with that of the Peijianchang section (Figure 6). Moreover, the highest-degree research of the Ediacaran Polcanco limestones in Uruguay was reported within the age of 590-560 Ma [50-53], which deposited after the Gaskiers glaciation. Natilie et al. [54] did detailed chemical analysis for the carbonates in Uruguay and observed that the dolomites $\delta^{13} \mathrm{C}$ values vary from $-2.7 \%$ to $0.2 \%$ and $\delta^{13} \mathrm{C}$ values for limestones in this region vary from $-3.1 \%$ to $0.4 \%$. These results are highly consistent with the $\delta^{13} \mathrm{C}$ values for the carbonates in the Suyukou section (Figure 6).

Based on the above analyses, we propose that the depositional time of the Zhengmuguan Formation is probably after the Gaskiers glaciation. Although the Tarim-Qaidam Block might have been separated from the Sino-Korean Block by the Qilian Aulacogen at that time [55,56], the coincident records of analogical glacio-marine deposits, paleo-environmental and fossils in both Tarim-Qaidam and Sino-Korean blocks together demonstrated that these two blocks were not far away from each other. Thus, we suggest that the Alxa Block (Helan Mountain) might be linked with the Tarim-Qaidam Block during the Sinian period [57].

At early Sinian, the western margin of the Ordos Basin began to receive deposits, formed a north-south marginal geotectogene and transgression took place along the geotectogene, extending from south to north. The Peijianchang area was located at the margin of the basin and thus the deposition thickness is smaller $(11.1 \mathrm{~m})$. The Tuerkeng area was located near the center of the basin, the deposition thickness is bigger $(100 \mathrm{~m})$. At the primary stage of the basin formation, a suit of glacial deposits occurred in the basin and this glaciation was adverse to biological reproduction. The organic matter burial in the ocean declined during this time, leading to the relative increase in the ${ }^{12} \mathrm{C}$ content in the deposits and the decrease in the inorganic carbon $\delta^{13} \mathrm{C}$ values [58]. The $\delta^{13} \mathrm{C}$ values of the Zhengmuguan Formation dolomites gradually decrease from bottom (old) to top (young) of the study sections, just consistent with the extremely cold climate during this period in the region.

In late Sinian, the glacier began to melt and the climate warmed up, the strata of the Tuerkeng Formation recorded deposits formed in a peritidal lagoon environment. The high $\mathrm{CO}_{2}$ concentration of the atmosphere during this time has caused stronger continental chemical weathering, resulting in prominent increase of trace elements as $\mathrm{Fe}, \mathrm{Mo}$, and the entrance of the nutrient element as $\mathrm{P}$ into the ocean. At the same time, the warm environment promoted complication of the eukaryotic cells $[59,60]$. Fortunately, the base layers of the Tuerkeng Formation contain abundant carbons, macro-body fossils, micro plant fossils and pyrite crystals and bandings, thus reflecting the warm environment in this period. All these characteristics show an increase of organic matter burial in the ocean during the late Sinian.

\section{Conclusions}

Detailed field work and carbon and oxygen isotopic analyses for the Sinian carbonates in the Helan Mountain, Ningxia show that the $\delta^{13} \mathrm{C}$ values for the Zhengmuguan Formation gradually decline from the bottom to up strata. The $\delta^{13} \mathrm{C}$ values vary from $-4.5 \%$ o to $-0.5 \%$, with a highly negative excursion around $-6.88 \%$. This is consistent with the $\delta^{13} \mathrm{C}$ negative excursion of global post-Gaskiers glaciation deposits. The observed $\delta^{13} \mathrm{C}$ variation patterns of the Sinian carbonates in the Helan Mountain suggest that the Sinian glacial deposits have developed in northern China, leading to sea level declining and an extremely cold climate. Marco-body fossils are abundant in the Tuerkeng Formation, implying that the climate has been warmed up during that time, along with the increasing organic matter burial in the seawater. According to the equivalent distribution of macro-body fossils in the Zhoujieshan Formation, Quanji system in the Qaidam Block and Dengying Formation in the South China Block, the depositional age of the Zhengmuguan and Tuerkeng formations are constrained to the Sinian period.

This work was supported by China Geological Survey (1212011120552). The authors thank Zheng Zhaochang with Institute of Geological Survey of Ningxia Bureau of Geology and Mineral Resources, Profs. Yang Weiran, Yang Sennan and Wang Jiasheng with China University of Geosciences, Wuhan for their significative suggestions. Res. Zhu Maoyuan with Nanjing Institute of Geology and Palaeontology, Chinese Academy of Sciences is thanked for his help with the identification of fossils. Prof. Huang Junhua with State Key Laboratory of Geological Processes and Mineral Resources, China University of Geosciences, Wuhan and Res. Xie Louhua with Guangzhou Institute of Geochemistry, Chinese Academy of Sciences are thanked for their help with carbon and oxygen isotopes analyses.

1 Kaufman A J, Knoll A H. Neoproterozoic variations in the C-isotopic composition of seawater: Stratigraphic and biogeochemical implications. Precambrian Res, 1995, 73: 27-49

2 Derry L A , Brasier M D, Corfield R M, et al. Sr and C isotopes in Lower Cambrian carbonates from the Siberian craton: A paleoenvironmental record during the "Cambrian explosion". Earth Planet Sci Lett, 1994, 128: 671-681

3 Kaufman A J, Knoll A H, Narbonne G M. Isotopes, ice ages, and terminal Proterozoic earth history. Proc Natl Acad Sci USA, 1997, 95: 6600-6605

4 Knoll A H. Learning to tell Neoproterozoic time. Precambrian Res, 2000, 100: 3-20 
5 Marshall J D. Climatic and oceanographic isotopic signals from the carbonate rock record and their preservation. Geol Mag, 1992, 129: $143-160$

6 Akihiro K, Yoko K, Tetsuhiro T, et al. Evolution of animal multicellularity stimulated by dissolved organic carbon in early Ediacaran ocean: DOXAM hypothesis. Isl Arc, 2011, 20: 280-293

7 Zhao Y Y, Zheng Y F. Record and time of Neoproterozoic glaciations on Earth (in Chinese). Acta Petrol Sin, 2011, 27: 545-565

8 Hoffman P F, Kaufman A J, Halverson G P, et al. A Neoproterozoic Snowball Earth. Science, 1998, 281: 1342-1346

9 Zheng Y F. The Location of the South China Block in Super-continental during Neoproterozoic (in Chinese). Chin Sci Bull (Chin Ver), 2004, 49: 715-717

10 Jiang G, Kennedy M J, Christie B N. Stable isotopic evidence for methane seeps in Neoproterozoic postglacial cap carbonates. Nature, 2003, 426: 822-826

11 Chumakov N M. A problem of total glaciations on the Earth in the Late Precambrian. Stratigr Geol Correl, 2008, 16: 107-119

12 Knoll A H, Walter M R, Narbonne G M, et al. A new period for the geologic time scale. Science, 2004, 305: 621-622

13 Hoffman P F, Li Z X. A palaeogeographic context for Neoproterozoic glaciations. Palaeogeogr Palaeoclimatol Palaeoecol, 2009, 277: 158172

14 Xu B, Zheng H F, Yao H T, et al. Carbon isotope composition and its significance of Sinian in the Tarim Block. Chin Sci Bull, 2003, 48: 385-389

15 Zhang Y, Wang P J, Liu W Z, et al. Sedimentary environment of the Neoproterozoic in Quruqtagh region (in Chinese). Xinjiang Geol, 2006, 24: 365-368

16 Zhang L, Du Y S, Zuo J X, et al. Negative anomaly of carbon isotope from carbonates of Sinian Dongpo Formation in Ruzhou and Lushan, Henan Province and its geological significance (in Chinese). J Earth Sci, 2008, 33: 523-530

17 Zhao Y Y. Sedimentary geochemistry characteristics of the Lantian Formation carbonates in southern Anhui (in Chinese). Dissertation for the Doctoral Degree. Hefei: University of Science and Technology of China, 2009. 108-126

18 Lv M, Zhu M Y, Zhao M J. Litho- and carbon isotope stratigraphy of the Ediacaran System in the Sixi Section (Yangtze Gorges), Yichang, Hubei (in Chinese). J Stratigr, 2009, 33: 359-372

19 Jiang G Q, Zhang S H, Shi X Y, et al. Chemocline instability and isotope variations of the Ediacaran Doushantuo basin in South China (in Chinese). Sci China Ser D-Earth Sci, 2008, 38: 1481-1495

20 Gu Q C. Late Pre-Cambrian Tillite in Helan Mountain (in Chinese). J Stratigr, 1982, 156-157

21 Zheng Z C, Li Y Z, Lu S N, et al. Report of the Zhengmuguan Formation in Helan Mountain (in Chinese). 1987

22 Zhang K. Tilloid at the bottom of the sedimentary covers on the margins of the Ordos Basin (in Chinese). Reg Geol Chin, 1991, 1: 79-85

23 Wang Z Q, Yin C Y, Gao L Z, et al. Chemostratigraphic studies to explain Neoproterozoic stratigraphic division and correlation (in Chinese). Earth Sci Front, 2006, 13: 268-279

24 Geology and Mineral Resources Bureau of the Ningxia Hui Autonomous Region. Lithostratigraphic of Ningxia Hui Autonomous Region (in Chinese). Wuhan: Chinese University of Geosciences, 1996. 2329

25 Geologiacal Environment Monitoring Station of Ningxia Hui Autonomous Region. J48C002003 (Yinchuan City) 1:250000 Regional Geological Survey Report (in Chinese). 2008

26 Ningxia Geological Surve. Ningxia Geology (in Chinese). Beijing: Geological Publishing House, 1990. 38-42

27 Xie L H, Wei G J, Deng W F, et al. Online analyses and multi-point calibration of the dirrerent forms carbon (in Chinese). In: Key Laboratory of Solid Earth Science Aliance Conference. Beijing: Geological Publishing House, 2012

28 Zhang T G, Chu X L, Zhang Q R, et al. Sulfur and carbon isotopes of the Doushantuo Period Paleo-Seawater (in Chinese). Chin Sci Bull (Chin Ver), 2003, 48: 850-855

29 Yang S P, Zheng S N. The Trace fossils of Zhengmuguan Foraion in the Helan Mountain, Ningxia (in Chinese). J Earth Sci, 1985, 10: 9-10

30 Li Y H, Yang S P, Li W Q. Trace Fossils Research on the SinianCambrian Boundary Transition Layers (in Chinese). Beijing: Geological Publishing House, 1997. 1-99

31 Hua H, Chen Z, Zhang L Y. Shaanxilithes from Taozichong Formation of Guizhou Province and its significance (in Chinese). J Stratigr, 2004, 28: 265-269

32 Shen B, Xiao S, Zhou C, et al. Carbon and sulfur isotope chemostratigraphy of the Neoproterozoic Quanji Group of the Chaidam Basin, NW China: Basin stratification in the aftermath of an Ediacaran glaciation postdating the Shuram event? Precambrian Res, 2010, 177: 241-252

33 Shen B, Xiao S, Dong L, et al. Problematic macrofossils from Ediacaran Successions in the North China and Chaidam Blocks: Implications for their evolutionary roots and biostratigraphic significance. J Paleontol, 2007, 81: 1396-1411

34 Zhao X S. Important progress on Precambrian geology research (in Chinese). Northwest Chin Geosci, 1992, 13: 129-138

35 Zhang L Y, Hua H, Xie C R. New progress and prospects for the Late Neoproterozoic Gaojiashan Biota (in Chinese). Chin Geol, 2001, 28: 19-24

36 Cai Y, Hua H, Xiao S, et al. Biostratinomy of the Late Ediacaran pyritized Gaojiashan lagerstatie from southern Shaanxi, South China: Importance of event deposits. Palaios, 2010, 25: 487-506

37 Mike M, James D, Schiffbauer, et al. Taphonomy of the Upper Ediacaran enigmatic ribbonlike fossil Shaanxilithes. Palaios, 2012, 27: 354-372

38 Halverson G P, Hoffman P F, Schrag D P, et al. Toward a Neoproterozoic composite carbon-isotope record. Geol Soc Am Bull, 2005, 117: 1181-1207

39 Guerrou L E, Allen P A, Cozzi A. Erratum to "chemostratigraphic and sedimentological framework of the largest negative carbon isotopic excursion in earth history: The Neoproterozoic Shuram Formation (Nafun Group, Oma-n)'. Precambrian Res, 2007, 153: 262265

40 Le Guerrou E, Allen P A, Cozzi A. Chemostratigraphic and sedimentological framework of the largest negative carbon isotopic excursion in earth history: The Neoproterozoic Shuram Formation (Nafun Group, Oman). Precambrian Res, 2006, 146: 68-92

$41 \mathrm{Xu} \mathrm{B}$, Jian $\mathrm{P}$, Zheng $\mathrm{H}$, et al. U-Pb zircon geochronology and geochemistry of Neoproterozoic volcanic rocks in the Tarim Block of northwest China: Implications for the breakup of Rodinia supercontinent and Neoproterozoic glaciations. Precambrian Res, 2005, 136: $107-123$

42 Xu B, Xiao S. SHRIMP zircon U-Pb age constraints on Neoproterozoic Quruqtagh diamictites in NW China. Precambrian Res, 2009, 168: 247-258

43 Zhu M Y, Wang H F. Neoproterozoic glaciogenic diamictites of the Tarim Block, NW China. Geol Soc Lond Mem, 2011, 36: 367-378

44 Xiao S H, Bao H M, Wang H F, et al. The Neoproterozoic Quruqtagh Group in eastern Chinese Tianshan: Evidence for a post-Marinoan glaciation. Precambrian Res, 2004, 130: 1-26

45 Shen B, Xiao S, Bao H, et al. Carbon, sulfur, and oxygen isotope evidence for a strong depth gradient and oceanic oxidation after the Ediacaran Hankalchough glaciation. Geochim Cosmochim Acta, 2011, 75: 1357-1373

46 Lu S N, Ma G G, Gao Z J, et al. Preliminary of Late Pre-Cambrian glacigeneous in China (in Chinese). Precambrian Geol, 1983, 1: 1-86

47 Prave A R, Fallick A E, Thomas C W, et al. A composite C-isotope profile for the Neoproterozoic Dalradian Supergroup of Scotland and Ireland. J Geol Soc Lond, 2009, 166: 845-857

48 Mccay G A, Prave A R, Alsop G I, et al. Glacial trinity: Neoproterozoic Earth history within the British-Irish Caledonides. Geology, 2006, 34: 901-912

49 Prave A R, Strachan R A, Fallick A E. Global C cycle perturbations recorded in marbles: A record of Neoproterozoic Earth history within the Dalradian succession of the Shetland Islands, Scotland. J Geol Soc Lond, 2009, 166: 129-135 
50 Gaucher C, Sial A N, Blanco G, et al. Chemostratigraphy of the lower Arroyo del Soldado Group (Vendian, Uruguay) and paleoclimatic implications. Gondwana Res, 2004, 7: 715-730

51 Blanco G, Rajesh H M, Gaucher C, et al. Provenance of the Arroyo del Soldado Group (Ediacaran to Cambrian, Uruguay): Implications for the paleogeographic evolution of southwestern Gondwana. Precambrian Res, 2009, 171: 57-73

52 Pecoits E, Gingras M, Aubet, et al. Ediacaran in Uruguay: Palaeoclimatic and palaeobiological implications. Sedimentology, 2008, 55: 689-719

53 Pecoits E. Ediacaran iron formations and carbonates of Uruguay: Palaeoceanographic, palaeoclimatic and palaeobiologic implications. Dissertation for the Doctoral Degree. Alberta: University of Alberta, 2010. 230

54 Natalie R A, Ernesto P, Andrey B, et al. Chemostratigraphic constraints on early Ediacaran carbonate ramp dynamics, Río de la Plata craton, Uruguay. Gondwana Res, 2012, 22: 1073-1090
55 Li T D. Lithospheric tectonic units of China (in Chinese). Chin Geol, 2006, 33: 700-710

$56 \mathrm{Wu}$ T R, He G Q. Tectonic units and their fundamental characteristics on the northern margin of the Alxa Block (in Chinese). Acta Geol Sin, 1993, 67: 97-108

57 Yang W R, Wang J, Liang X. The major characteristics of geotectonics of Asia and regularities of evolution (in Chinese). Earth Sci Front, 2012, 19: 1-17

58 Lambert I B, Walter M R, Zang W. Paleoenviroment and carbon isotope stratigraphy of Upper Proterozoic carbonates of the Yangtze Platform. Nature, 1987, 325: 140-142

59 Dahl T W, Hammarlund E U, Anbar A D, et al. Devonian rise in atmospheric oxygen correlated to the radiations of terrestrial plants and large predatory fish. Proc Natl Acad Sci USA, 2010, 107: 1791117915

60 Noah J P, Olivier J R, Andrey B, et al. The evolution of the marine phosphate reservoir. Nature, 2010, 467: 1088-1090

Open Access This article is distributed under the terms of the Creative Commons Attribution License which permits any use, distribution, and reproduction in any medium, provided the original author(s) and source are credited. 